\title{
Application of Communication Skills (CS) Among Lecturer on Vocational Teaching and Learning in Vocational College Zone Johor, Malaysia
}

\author{
Mohd Hasril Amiruddin, Faizal Amin Nur Yunus, Mohamad Hisyam Mohd Hashim, \\ Mohd Bekri Rahim, Mohd Luqman Abd Rahim
}

Faculty of Technical and Vocational Education, Universiti Tun Hussein Onn Malaysia, Johor, Malaysia

Email address:

hasril@uthm.edu.my (M. H. Amiruddin), faizaly@uthm.edu.my (Y. F. A. Nur), mhisyam@uthm.edu.my (M. H. Mohd Hashim), bekri@uthm.edu.my (R. M. Bekri), sampaliola@gmail.com (M. L. A. Rahim)

\section{To cite this article:}

Mohd Hasril Amiruddin, Faizal Amin Nur Yunus, Mohamad Hisyam Mohd Hashim, Mohd Bekri Rahim, Mohd Luqman Abd Rahim. Application of Communication Skills (CS) Among Lecturer on Vocational Teaching and Learning in Vocational College Zone Johor, Malaysia. International Journal of Vocational Education and Training Research. Vol. 1, No. 4, 2015, pp. 55-61.doi: 10.11648/j.ijvetr.20150104.11

\begin{abstract}
This study aims to identify the application of communication skills among vocational lecturer at the Vocational College in Johor, Malaysia. In particular, this study attempts to look at the implementation of lecturers in terms of communication skills with demographic factors and the level of implementation of the lecturer when teaching and learning. A total of 186 respondents were selected to answer a questionnaire. Respondents were selected from vocational college lecturers who teach in the field of vocational around Johor. Data's were analyzed using frequency and percentage, mean score, T-test and Pearson correlation test. The results showed a lecturer in vocational colleges can apply with excellent communication skills and effectively. The findings also showed that there is no significant difference in the application of communication skills among lecturers of the opposite sex and there is no significant relationship between the application of communication skills in the field of teaching and the teaching experience of lecturers. Some suggestions have been made to ensure and improve the application of communication skills among lecturers at colleges that can be implemented to further research.
\end{abstract}

Keywords: Communication Skill, Vocational Collage, Teaching and Learning, Generic Skill

\section{Introduction}

Unemployment among graduates is serious to ensure the development of the national economy is in a high level. This can be seen by a study produced by a company Manpower Staffing Services (M) Sdn Bhd through its manager Sam Haggang found that three out of five university graduates will take more than 6 months to fill the vacancies that exist in Malaysia. While the other $40 \%$, took longer to fill existing vacancies. This shows that graduate unemployment rate in Malaysia is high. Talent Corp report also mentions the weaknesses of today's graduates are communication skills, English language proficiency and leadership. Furthermore, $81 \%$ of employers agree that communication skills among graduates is at a less than satisfactory while $56 \%$ were less creative and critical. The requirements of employers is important for them to make their products more competitive in the industry are doing well.

The graduates need to prepare themselves with various skills to ensure they can captivate employers. According to [33] most employers now require workers who not only have technical skills but also require generic skills to improve the productivity of a company. The level of their mastery of generic skills is weak. These include communication skills often emphasized by the employer. This is supported by the fact [28] confirming the level of generic skills among students in Bachelor of Technology and Education was weak during industrial training. Generic skills are emphasized communication skills, teamwork skills, problem solving skills, etc., all these skills will help graduates to find a job more easily and reduce unemployment.

A study [4] found that $86 \%$ of employers consider that good communication skills are very important, and most employers are less satisfied with the way the graduates presented themselves effectively. Khazanah also in its study has identified eight criteria set a priority for employers where most graduates still fail to meet the communication skills orally and in writing, flexibility and mobility, a desire for learning, presentation skills, proactive behavior, 
interpersonal skills, abilities to produce ideas and good discipline.

Communication skills are essential for graduates to venture into a job where most employers emphasize communication skills in the selection of their new employees. This was also supported in the Human Resources Development report that states an adult student problem now is the lack of communication even entered into the working world. Vocational colleges were among the coatings to generate professional technical workers in the field of vocational training. They are the engine of the highly skilled workers who triggered by the Ministry of Education to be implemented from an early age. Therefore, the application of which this young age is important before they enter into the realm of the university and on to the field of employment that are more difficult to set up their communication skills. Therefore, a study should be conducted to see how the application of communication skills among young lecturers to students today.

\section{Methodology}

Researchers have used a quantitative approach for doing this research. The study was conducted using a survey design which survey method is an efficient method of collecting data. Survey or the survey study is one not of an experimental research methods are most popularly used in various fields, especially in the social sciences. Survey also widely used in the fields of education and the design is suitable for use by researchers to study the application of communication skills among vocational lecturers in teaching and learning in vocational colleges Johor zone. In this study, the first stage is to identify problems the study. When problems were identified, the instrument is designed for the data collection process and the next sample is selected to carry out the study. After that, a pilot study was conducted to determine the validity and reliability of the instruments used. There are findings that have been analyzed data used for discussion and writing research reports on the process of collecting data for the actual study is completed.

\subsection{Population and Sample}

The population selected for this study is a lecturer at the College of Vocational Johor zone, in Malaysia. Population size for lecturers who teach in the field of vocational at a vocational college Johor zone is about 413 people, where it is taken based on the number of courses taken from the list of courses in vocational colleges from the website Bahagian Pendidikan Teknikal dan Vokasional (BPTV). Target sample is only lecturer from the field of vocational training. The researchers chose sampling technique is simple random sampling technique. Researchers have obtained the list of lecturers who teach in the field of vocational training only from the administration of the college and get a list supplied by the respondents. The number of samples taken by the sampling schedule [31], in which he suggested the number may be necessary to make these samples according to the lecturer's generalized population is comprised of 186 .

\subsection{The Research Instrument}

Questionnaires to be the main instrument in this study because these instruments are easily administered and researchers save time during data collection. The questionnaire used was adapted from a survey conducted last year by researchers of [22]. Some modifications have been made to meet the objectives of this study. The questionnaire consists of 55 items and is divided into 3 parts, part A (demographic), part B (knowledge about communication skills lecturer) and C (application of communication skills in teaching and learning).

Pilot study to find the reliability of questionnaire items for this study were made using samples which have been isolated and does not participate in the actual research that has been conducted. Studies were done in Batu Pahat Vocational College using 30 respondents drawn from each of the lecturers in the field that is in college. This is to ensure that the samples for this pilot study are similar to actual research conducted. The reliability of the questionnaire items that have been built have passed the minimum requirements and all items are acceptable for use in the actual study with the Cronbach alpha.776. A total of four lecturers from the Department of Professional Education experts consulted for confirmation of the validity of the face and content validity of the questionnaire and the verification form questionnaire.

\subsection{Data Analysis}

All data is collected, coded and analyzed using Statistical Package for Social Science (SPSS) version 21.0. Prior to the analysis carried out, filtered data in advance. Data filtering carried out to look at actual features that existed before the analysis can be carried out. Screening is also carried out to identify the existence of missing value arising from the failure of the respondent to answer a questionnaire that was given and which may affect the analysis of data.

Data analysis processes involves several methods such as descriptive analysis of frequency, percentage and mean score while inference analysis using t-test for parametric test, such as the correlation table 2.1 .

Table 2.1. Methods of data analysis.

\begin{tabular}{|c|c|}
\hline Research Questions & Analysis Methods \\
\hline $\begin{array}{l}\text { Do lecturer in Vocational College Johor zone, } \\
\text { know about communication skills description? } \\
\text { What is the level of communication skills as a } \\
\text { lecturer for vocational teaching at vocational } \\
\text { college? }\end{array}$ & $\begin{array}{l}\text { The Frequency and } \\
\text { Percentages } \\
\text { Min Score }\end{array}$ \\
\hline Research Hypothesis & Analysis Methods \\
\hline $\begin{array}{l}\text { Ho: There was no significant difference } \\
\text { between genders with the application of } \\
\text { communication skills among lecturers } \\
\text { Vocational College. }\end{array}$ & T-test \\
\hline $\begin{array}{l}\text { Ho: There was no significant relationship } \\
\text { between teaching experiences of the } \\
\text { application of communication skills among } \\
\text { lecturers Vocational College. }\end{array}$ & Pearson Correlation \\
\hline
\end{tabular}


Table 2.1. Methods of data analysis. (cont.).

\begin{tabular}{l|l}
\hline $\begin{array}{l}\text { Ho: There was no significant relationship } \\
\text { between teaching field on the application of } \\
\text { communication skills among lecturers }\end{array}$ & Pearson Correlation \\
Vocational College. & \\
\hline
\end{tabular}

\section{Result}

A total of 186 respondents provided feedback to a questionnaire that had been distributed. Table 3.1 shows that $49 \%$ or 94 of the respondents in this study were males, while a total of 96 respondents or $51 \%$ were women.

\subsection{Demographics of Respondents}

Table 3.2 shows that $25 \%$ or a total of 48 of the respondents in this study had less than 5 years experience, a total of 33 respondents or $17 \%$ had 6 to 10 years of experience, as many as 22 people or $12 \%$ have the experience of 11 to 15 years, a total of 33 or $17 \%$ of people have the experience of 16 to 20 years and a total of 54 people or $28 \%$ of lecturers who have been teaching for more than 20 years.

Table 3.1. Frequency and percentage of respondents gender.

\begin{tabular}{lcc}
\hline Gender & Frequency & Percentage (\%) \\
\hline Male & 94 & 49 \\
Female & 96 & 51 \\
Total & 190 & 100 \\
\hline
\end{tabular}

Table 3.2. Frequency and percentage of lecturers teaching experience.

\begin{tabular}{lcc}
\hline Teaching Experience & Frequency & Percentage (\%) \\
\hline Less than 5 years & 48 & 25 \\
6 to 10 years & 33 & 17 \\
11 to 15 years & 22 & 12 \\
16 to 20 years & 33 & 17 \\
More than 20 years & 54 & 28 \\
Total & 190 & 100 \\
\hline
\end{tabular}

Table 3.3. Frequency and percentage of field of teaching vocational college lecturers.

\begin{tabular}{lcc}
\hline Teaching Field & Frequency & Percentage (\%) \\
\hline Electrical Technology & 26 & 14 \\
Electronic Technology & 44 & 23 \\
Machining Technology Industry & 12 & 6 \\
Refrigeration and Air Conditioning & 9 & 5 \\
Technology & 4 & 2 \\
Fashion and Clothing manufacturing & 12 & 6 \\
Child Care Services & 3 & 2 \\
Culinary Arts & 10 & 5 \\
Automotive Technology & 8 & 4 \\
Welding Technology & 20 & 11 \\
Construction Technology & 9 & 5 \\
Cosmetology & 33 & 17 \\
Others & 190 & 100.0 \\
Total & & \\
\hline
\end{tabular}

Table 3.3 shows the number and percentage of respondents in the courses taught at the Vocational College. Table 4.3 shows the courses of Electrical Technology has a total of 26 people or $14 \%$, Electronic Technology has a total of 44 people or 23\%, Industrial Machinery Technology has a total of 12 people, or $6 \%$, Refrigeration and Air Conditioning Technology has a total of 9 people or $5 \%$, Fashion and Clothing manufacture of 4 or $2 \%$, Child Care Services 12 people or $6 \%$, Culinary Arts 3 people or $2 \%$, Automotive Technology as many as 10 people or $5 \%$, Welding Technology group of 8 persons or $4 \%$, of Construction Technology 20 people or $11 \%$, Cosmetology 9 people or $5 \%$, and other fields of 33 people or $17 \%$ of the respondents.

\subsection{Knowledge of Lecturers on Description of Communication Skills}

This section describes the knowledge lecturer on communication skills description outlined by the Ministry of Education in soft skills modules. Table 3.4 shows that 180 people or $95 \%$ of lecturers understand the concept of communication skills and 10 people or $5 \%$ still do not understand the concept of communication skills outlined in the module.

Table 3.4. Frequency and percentage of lectures ondescription of communication skills.

\begin{tabular}{lll}
\hline Understanding & Frequency & Percentage \\
\hline Yes & 180 & 95 \\
No & 10 & 5 \\
Total & 190 & 100 \\
\hline
\end{tabular}

\subsection{The Level of Communication Skills}

All sub constructs have a high level of mean scores of 3.92 (standard deviation $=.50$ ), indicating the level of communication skills by vocational lecturers is high and bright as table 3.5 .

Table 3.5. Overall analysis of score min for the level of communication skills application.

\begin{tabular}{llll}
\hline & Sample & Min & Standard Deviation \\
\hline Application of CS & 190 & 3.92 & .50 \\
\hline
\end{tabular}

\subsection{The Difference Between Gender with the Application of Communication Skills}

T-test was performed to make a comparison between two groups of male sex and female lecturers. The findings revealed that there is a difference between male and female variable with the following value $(\mathrm{t}=.599, \mathrm{p} \geq .05)$. Results in Table 3.6 allows researchers failed to reject the null hypothesis and showed no significant difference between male lecturers with a lecturer of women in the application of communication skills in vocational colleges.

Table 3.6. Results of t-test.

\begin{tabular}{|c|c|c|c|c|c|c|}
\hline \multirow{3}{*}{$\begin{array}{l}\text { Applicationof } \\
\text { CS }\end{array}$} & Gender & $\mathbf{N}$ & Min & $\begin{array}{l}\text { Std. } \\
\text { Dev. }\end{array}$ & $\mathbf{t}$ & $\begin{array}{l}\text { Sig. } \\
\text { Lev, p }\end{array}$ \\
\hline & Male & 94 & 3.94 & .52 & \multirow{2}{*}{.599} & \multirow{2}{*}{.550} \\
\hline & Female & 96 & 3.90 & .48 & & \\
\hline
\end{tabular}




\subsection{The Relationship Between Teaching Experience with the Application of Communication Skills}

Pearson correlation test was carried out to find the relationship between lecturers teaching experience with the application of communication skills. Table 3.7 shows that there was no significant relationship between lecturers teaching experience with the application of communication skills with the.283 significant ( $\mathrm{p}>.05)$, meaning Ho accepted. The table also shows that there is a very weak negative correlation with the correlation coefficient is -.08 , which means the longer the less experienced lecturers application of communication skills. These results indicate that the teaching experience of lecturers have very weak and there was no significant association with the application of communication skills by the lecturers to the students in vocational colleges.

Table 3.7. The relationship between the application of communication skills with lecturers teaching experience.

\begin{tabular}{lll}
\hline & & Application of CS \\
\hline Lecturer & Pearson correlation, $\mathrm{r}$ & -.08 \\
Teaching & Significant level, $\mathrm{p}$ & .28 \\
Experience & Sample, $\mathrm{n}$ & 190 \\
\hline
\end{tabular}

\subsection{The Relationship Between the Fields of Teaching and Communication Skills}

Pearson correlation test was carried out to find the relationship between lecturers teaching field through the application of communication skills. Table 3.8 shows that there was no significant relationship between lecturers teaching experience with the application of communication skills with the. 01 significance $(p>.05)$, which means Ho fail rejected. The table also shows that there is a weak negative correlation with the correlation coefficient is -.18. These results indicate that the teaching experience of lecturers have very weak and there was no significant association with the application of communication skills by the lecturers to the students in vocational colleges.

Table 3.8. The relationship between the application of communication skills with lecturers teaching field.

\begin{tabular}{lll}
\hline & & Application of CS \\
\hline \multirow{2}{*}{ Lecturers } & Pearson correlation, $\mathrm{r}$ & -.18 \\
Teaching Field & Significant level, $\mathrm{p}$ & .06 \\
& Sample, $\mathrm{n}$ & 190 \\
\hline
\end{tabular}

\section{Discussion}

\subsection{Discussion on Knowledge Communication Skills Lecturer About Disclosures}

The results showed that more female respondents than male respondents bit where only two people who distinguish between them. The findings also showed that the majority respondents answered "YES" and minority answered "NO".

Based on the analysis performed, an element that is dominated by lecturers is the ability to practice active listening skills, while "element of communication skills" most vulnerable dominated by lecturers is the ability to use non-verbal skills.

Based on these findings, it shows that the lecturers deeply understand the needs of a student when learning activities are carried out which they have to listen well to get the right information and appropriate. According [34] a study of high school students showed that students were using $46 \%$ of their time at school to listen only and $60 \%$ of the activity of the hearing is to hear the conversation teacher. This is also supported by [39] who said about $60 \%$ of the time is used for listening.

The results for the most number of lecturers weak skills are mastered non-verbal communication skills in which the non-verbal aspect, the problem is that teachers are not able to show the appropriate facial expressions. Facial expressions are important when explaining or describing something. [41] also added, that the knowledge and skills of teachers in these subjects was not adequate for students to receive all the information submitted. This is because non-verbal aspects help in his teaching. Proper application of body language and can also lead to a situation in conformity with the help communicate what you want delivered. This was also supported by [42] eye contact can indicate positive feelings such as love, joy and earnest. Eye contact also contribute to effective teaching and learning in the classroom.

\subsection{Discussion on Application Level Communication Skills Lecturer Vocational}

This section discusses the level of communication skills by vocational lecturers in vocational college Johor zone. Based on the findings, it shows the level of overall communication skills lecturer is at a high level. eight elements of communication skills showed findings that the highest level of application is a lecturer in reading skills, communication skills and the level of implementation is the lowest writing skills.

Overall, the results of this study showed that the application of communication skills is high and meets the formulation that states that interpersonal communication skills are very important in an organization. This is also supported by a study of [43] concluded that their findings implementing phase soft skills through class platform among students in secondary technical schools is at a high level this includes communication skills. This study showed researchers did not run from several previous studies that showed the level of implementation of these communication skills in high level.

Reading skills deemed to be a process to obtain a meaningful interpretation of the symbols printed or written is important in interpreting [44]. These skills form the elements of implementing the highest in the study where it is important for students to interpret such information correctly, since most equipment and the environment in workshops and practical classes require students to vocational stream take you about safety using symbols. There is also the reading process many types of students understood before action is taken as read as sensory processes (sensation), read as a process of observation, reading as a process of language and reading is a cognitive process [45]. 


\subsection{Discussion on Gender Differences with the Implementation of Communication Skills Lecturer}

Results showed that there was no significant difference between men and women in applying communication skills. Researchers feel that communication skills can not only be controlled by a gender. This is also supported by [46] which says that talking is actually a kind of talent and the study found no significant difference in communication skills between the sexes.

In the view of researcher communication skills for vocational stream is not influenced by the gender of a lecturer for vocational learning and teaching more focused on practical skills that students need to master the ability to use your hands (hands on). It shows communication skills of lecturers, men and women are equal in generating skilled students and what needs to be improved is the confidence to deliver information to students.

The findings show that gender is not an important factor in applying communication skills to students. Lecturer male or female teachers can apply their communication skills if they are well confident to interact with students and can deliver good teaching content.

\subsection{Discussion on the Relations of Teaching Experience with Implementation of Communication Skills Lecturer}

The findings of this study show that teaching experience of lecturers do not have a significant relationship with implementing communication skills by the lecturers to the students in vocational colleges. This is supported by the findings of a study conducted [47] found that factor does not affect the efficacy of teacher experience and the findings of this study differ from findings by [47] who said that experienced teachers teach more than seven years tending believes high in student participation, teaching strategies and classroom management. The findings of this study may have been influenced by the number of samples is used where only concentrated in Johor zone.

The researcher believes vocational field more closely related to the use of high-tech equipment and new tools that help teach the teachers who have over 20 years of teaching experience need time to gain knowledge of using modern equipment and new lecturers who have been exposed to more recent use of tools and they are necessary to ensure long-serving teachers who have new knowledge.

The results showed that the lecturers teaching experience does not affect implementing communication skills in teaching and learning in vocational colleges Johor zone. The new and old lecturers should work together to ensure more effective communication in disseminating information accurately and correctly [48].

\subsection{Field relationships Teaching Communication Skills with Implementation of Lecturer}

The study found that no significant relationship between the field and the implementing communication skills taught by lecturers. The researcher argues for vocational teaching areas are different for implementing communication skills due to equipment and environment are different between these areas and this causes the delivery of instruction is different and has different communication implementing between fields. This is supported by studies [49] in which he states that there are various ways to attract student teachers during teaching and learning process in the classroom, one of which is the use of teaching aids attractive. The use of teaching aids such as charts, graphs, and graphs can explain more of a concept presented by the teacher [50].

A wide range of vocational courses that they offer, and they offer different fields such as automotive and fashion environment where the surrounding atmosphere is very different and this leads to the way they communicate differently and there is no similar relationship in applying communication skills to students. This is supported by [51] who said that TVET is difficult to keep up with today's technology.

\section{Conclusion}

Based on the discussions that have clarified concluded that lecturers vocational stream can apply with good communication skills and are not influenced by their background. Without meaning, purpose, and does not cause confusion or misunderstanding when presenting information to students is to use effective communication alone can do it all. Teachers who become the recipients of media or language student needs to have knowledge about the characteristics of good communication and will be helping with the goal of effective communication. By adopting the features and goals of the national education philosophy until now it shows link and close relationship with the characteristics of effective communication between students and lecturers and lecturers with the pentadbiran.ini have menjadikansemua involved in an educational institution to understand and practice communication effective to produce a quality basic education.

Researchers want to give some recommendations to management to make college lecturer has been consistent, namely:

i) Provide courses related to new communication skills to enhance the lecturers such as the use of humor in teaching and others.

ii) To ensure that lecturers always give a high commitment to communicate with the student, mentor mentee program may help the lecturers to the students more confident and know that they are easy to communicate.

\section{References}

[1] Alias Baba (1988). Concept mapping: A Strategy for Teaching and Learning. Journal of Education. 2, 25-29.

[2] Ary, D., Jacobs, L. C., \& Razavieh, A. (2002). Introduction to research in education. Fort Worth, TX: Holt, Rinehart and Winston. 
[3] Ary, D. (2006). Introduction to research in education (7th Ed.). Belmont, CA: Thomson Wadsworth.

[4] Archer, W. \& Davison, J. (2008). Graduate Employability: What Do Employers Think and Want. The Council for Industry and Higher Education, London.

[5] Atan Long (1980). Educational Psychology. Kuala Lumpur: Dewan Bahasa dan Pustaka.

[6] Azizi Yahaya. (2007). Master of Research in Education: theory, analysis and interpretation of data. Batu Caves, Selangor: PTS Professional Publishing Sdn. Bhd.

[7] Banks, J.A. (1990). The dimensions of multicultural education. Multicultural Leader.Vol 3. Edmonds, WA.

[8] Berg, K.E. \& R.W. Latin. (2004). Essentials of research methods, in health, physical education, exercise science and recreation. Second ed. 2004, Philadelphia: Lippincott Williams \& Wilkins.

[9] Berita Harian, 13 Mac 2011. Harian Metro, pp: 45, Thursday, 1 November 2012.

[10] Brown G. (1975). Micro Teaching: A Programmed of Teaching Skills, Methuen \& Co. Ltd. London,

[11] Bloom B. S. (ed.): Taxonomy of Education Objectives, Book 1, Cognitive Domain, Croomhelm, London.

[12] Cohen, L \& Manion. (1983). Guide to Teaching Practice, Great Britain, the Chaner Press Ltd.

[13] Connell, W. F. (1981). Asas Pendidikan, Dewan Bahasa dan Pustaka, Kuala Lumpur.

[14] Crow, L. D. \& Crow, A. (1980). Psikologi Pendidikan Untuk Perguruan, Dewan Bahasa dan Pustaka, Kuala Lumpur.

[15] Cryer, P. (2001). The research student's guide to success. Buckingham: Open University Press.

[16] Chua, Yan Piaw. (2006). Kaedah penyelidikan. Kuala Lumpur: McGraw-Hill.

[17] Daily Express, pp: 5 Tarikh: Sabtu, 27 Oktober 2012.

[18] Dececco, J. P. (1968). The Psychology of Learning and Instruction: Educational Psychology, Prentice-Hall, New Jersey.

[19] Emat.Y. (2005). Cabaran Dan Strategi Pendidikan Teknik Dan Vokasional Ke Arah Mencapai Wawasan 2020. Jurnal Pendidikan, Jilid 37 Keluaran 8 Jun 1993, Kementerian Pendidikan Malaysia. Retrieve pada September 25, 2011 from http://aede.tripod.com/Vok.htm.

[20] Hillage, J. \& Pollard, E. (1998). Employability: developing a framework for policy analysis. Research Brief 85, Department for Education and Employment, London.

[21] Hind, D \& Moss, S. (2005). Employability skills, Sunderland: Business Education Publishers.

[22] Ismail, N. \& Wok, S. (2002). Kursus Komunikasi Organisasi. Kuala Lumpur Universiti Putra Malaysia.

[23] Johnson, B., \& Christensen, L. (2004). Educational research: Quantitative, qualitative, and mixed approaches (2nd ed.). Boston, MA: Pearson.
[24] Keeves, J. P. (Ed.). (1998). Educational research, methodology, and measurement: An international handbook. Oxford: Pergamon.

[25] Mohamed Amin Embi. (2011). Panduan Amalan Pengajaran \& Pembelajaran Berkesan, Educator \& Trainer in e-Learning at Universiti Kebangsaan Malaysia.

[26] Mohd. Sharani Ahmad. (2004). Mengurus Kanak-Kanak Yang Susah Belajar. PTS Publications \& Distributors.

[27] Mohd Zuri Ghani \& Aznan Che Ahmad. (2011). Kaedah dan Strategi Pengajaran Kanak-Kanak Berkeperluan Khas, Publisher Universiti Sains Malaysia.

[28] Noraini Mohd Saleh. (2001). Penyelidikan kualitatif: Pengalaman kerja lapangan penyelidikan. Editor Mohaini Yusof. Kuala Lumpur: Universiti Malaya.

[29] Noresah. (2002). Kamus Dewan Edisi Ketiga, Kuala Lumpur, Dewan Bahasa Dan Pustaka.

[30] Nurul Najmi Abd Manab. (2007). Tahap Kemahiran Generik di Kalangan Pelajar Sarjana Muda Teknologi Serta Pendidikan (PTK) Semasa Menjalani Latihan Industri. Degree Tesis. Universiti Teknologi Malaysia, Skudai.

[31] Kamsah, Mohd Zakidan Abu, Mohd Salleh \& Razzaly, Wahid. (2008). Penerapan kemahiran insaniah (KI) kepada pelajar dalam aktiviti pengajaran \& pembelajaran di IPTA. Dalam: Seminar Kebangsaan Kemahiran Insaniah dan Kesejahteraan Sosial (SKIKS) 2008, 18 Ogos 2008, Hotel Mahkota, Melaka.

[32] Krejcie \& Morgan. (1970). Determining Sample Size for Research Activities. Educational and Psychological Measurement. \#30, 607-610.

[33] Kementerian Pengajian Tinggi Malaysia. (2006). Modul pembangunan kemahiran insaniah (soft skills) untuk institusi pengajian Tinggi Malaysia. Serdang: Penerbit UPM, 155.

[34] Koh Boh Boon, John Arul Phillips, \& Norani Mohd. Salleh. (1983). Pengajaran dan pembelajaran sivik di sekolah-sekolah Malaysia. Kuala Lumpur: Utusan Publications \& Distributors.

[35] Polisi Kebebasan Akademik dan Kecemerlangan Profesional, Nombor Polisi: UTM.P.A.0.4, Diluluskan Oleh: Senat: 8 Ogos 2011, Tarikh Kuat kuasa: 8 Ogos 2011, Semakan Terakhir: 8 Ogos 2011 (Tarikh akhir semakan semula 8 Ogos 2014).

[36] S. Muda. (2011). Factors Influencing Skills Mastery Level Communications Prime among Students in Year 4 Bachelor of Technology and Education (Res. Public, Gen. Electricity, Eng. Machinery and Life Skills) At the University of Technology Malaysia.

[37] Sabitha Marican. (2005). Kaedah Penyelidikan Sains Sosial. Petaling Jaya, Selangor: Prentice Hall.

[38] Siti Maspah Hassan \& Nor Azizah Mohd. Salleh. (1995). Kertas Kerja Bertajuk: Pendidikan Vokasional- Formal Dan Non Formal Ke Arah Wawasan 2020. Dalam Seminar Kebangsaan Pendidikan Negara Abad Ke 21 di UKM, Bangi pada 9 November 1995.

[39] Valiance, R. J. (2004). Formation in research ethics: Developing a teaching approach for the social sciences. Kertas kerja yang di bentang dalam AARE Conference 28 November - 2 Disember 2000.

[40] Yahya Othman. (2003). Teaching Reading, Theory \& Applications, User Increase. Teaching Reading skills. Selangor: PTS Publications \& Distributors Sdn. Bhd. 
[41] Nor Shafrin Ahmad, Fadzilah Amzah \& Rahimi Che Aman. (2009). Kemahiran Komunikasi Guru Pelatih Universiti Sains Malaysia. Jurnal Pendidik dan Pendidikan, Jilid. 24: 125-142

[42] Abdul Hamid Mahmood. (1990). Penguasaan Bahasa Malaysia Baku di Kalangan Pelajar-pelajar. Jurnal Dewan Bahasa, April: 243-52.

[43] Fadilah Mat Assain@Hashim \& Hasmadi Mat Safar. (2011). Penerapan Kemahiran Insaniah Di Sekolah Menengah Teknik: Satu Analisis Perbandingan. Degree Tesis. Universiti Tun Hussein Malaysia.

[44] Harris, Albert j. \& Sipay, Edward R. (1975). How to Increase Reading Ability, New York: Longmans, Green \& Co.

[45] Marohaini Yusoff. (1999). Strategi Bacaan dan Kefahaman. Kuala Lumpur: Dewan Bahasa dan Pustaka.

[46] Abdullah Hassan \& Ainon Mohd. (2000). Seni Bercakap-cakap dan Berbual-bual. Bukit Tinggi: Penerbit PTS.

[47] Woolfolk Hoy, A. (1998). Complexity and coherence: An essay review of theHandbook of educational psychology. Teachers College Record, 100, 437-452.
[48] N. Othman \& M. H. Amiruddin. (2010). Different perspective of learning styles from VARK model, Procedia Social and Behavioral Sciences, vol. 7, pp. 652-660.

[49] Sulaiman Ngah Razali. (1996). Analisis Data Dalam Penyelidikan. Kuala Lumpur: Dewan Bahasa dan Pustaka.

[50] N. Othman, M. H. Amiruddin, \& M. Mansor. (2011). The entrepreneurial behavior of Orang Asli youths in south peninsular Malaysia," International Journal of Education and Information Technologies, vol. 1 no. 5, pp. 132-139.

[51] Noor Hareezan. (2002). Persediaan Pelajar Institut Latihan Perindustrian Pasir Gudang Memasuki Pasaran Kerja Di Sektor Perindustrian, satu Tinjauan. Degree Tesis Universiti Teknologi Malaysia, Skudai.

[52] Johari Hassan dan Nik Selma Muhammad. (2011). Faktor-faktor Yang Menyebabkan Masalah Ponteng Sekolah di Sekolah Menengah Daerah Kulai Jaya, Johor. Degree Tesis Universiti Teknologi Malaysia, Skudai. 